\title{
Information System and Firms' Performance: The Case of Malaysian Small Medium Enterprises
}

\author{
Saira Kharuddin (Corresponding author) \\ Dept. of Accounting and Finance, Faculty of Economics and Management, Universiti Putra Malaysia \\ 43400 UPM Serdang, Selangor Darul Ehsan \\ Tel: 60-3-8946-7630Ｅ-mail: saira@econ.upm.edu.my
}

Zariyawati Mohd Ashhari

Dept. of Accounting and Finance, Faculty of Economics and Management, Universiti Putra Malaysia 43400 UPM Serdang, Selangor Darul Ehsan

Tel: 60-3-8946-7630Ｅ-mail: zariyawati@gmail.com

Annuar Md Nassir

Dept. of Accounting and Finance, Faculty of Economics and Management, Universiti Putra Malaysia 43400 UPM Serdang, Selangor Darul Ehsan

Tel: 60-3-8946-7630Ｅ-mail: annuar@econ.upm.edu.my

\begin{abstract}
Information systems are widely use by many corporations to automate existing operations and to improve business activities efficiency. Prior researches have shown that information system adoption did increased firms' performances and operations efficiency. In Malaysia, Small and Medium Enterprises (SMEs) has been targeted as a mechanism in generating domestic-led investment to stimulate economic development, particularly after the economic crisis that hit the country in 1997. Thus, it is crucial for SMEs to adopt information system to enhance their business operations capability and efficiency. Nevertheless, SMEs limited resources to implement information systems have been one of the critical barriers that hindered the adoption of information systems. Malaysian government has allocated special grants and various initiatives to assist Malaysian SMEs to adopt information system software. Therefore, this study is to investigate the impact of accounting information system on firm performance of Malaysian SMEs. Panel data was used to analyse firm's performance. Results revealed that SMEs adopting accounting information system show significant improvement in performance compared to non-adopters.
\end{abstract}

Keywords: Accounting systems, SMEs, Firm performance, Random effect

\section{Introduction}

The growth of computer technology in 1950s had initiated increasing development in information storing and processing (Rashid, Hossain, \& Patrick, 2001). Computer technologies increase the use of information due to its capabilities of analysing massive amount of data and in producing accurate and timely reports. These unique features of computer capabilities have lead to the introduction of various information systems such accounting information system (AIS), manufacturing resource planning system (MRP) and human resource system (HRM). Information system technology has definitely changed the way businesses are being operated (Elliot, 1992). Firms that are responsive to these changes are perceived to be able to gain competitive advantage (Porter, 1980; Fisher and Kenny,2000).

Computer revolutions have greatly affected many organisation processes and procedures, in particular the accounting process (Ismail, Abdullah, \& Tayib, 2003). In the early 1960s, many organizations have started utilizing Inventory Control Packages (ICP) technology to integrate and automate their inventory control system (Rashid, Hossain, \& Patrick, 2001). This system has contributed to increases in business productions and transactions as now firms are able to produce more products due to the more systematic order schedule plan offered by the system. Thus, this enhances business activities. More businesses and transactions implied that there will be more accounting data needed to be recorded and updated. Prior traditional accounting method of manually inputting and recording daily transactions has becoming inefficient. Errors such as wrong data entry, inefficient tasks performance and massive utilization of paper products have create many problems to business 
activities and organization's performance. These inadequacies have led to the emergence of accounting information system. A system that is able to gather, analyse and produce reports more efficiently.

The economic crisis that hit Malaysian economy in 1997/1998 has been an eye opener to many people, organizations, and government agencies on SMEs contributions. When many major corporations and foreign investors withdrew their investments and move them to new destinations, Malaysian SMEs remained functioning. Their struggle and continuous effort to stay in business provide significant contributions in assisting the country to confront the economic challenges. In addition, many studies asserted that SMEs form an essential component of many economies. In some advanced countries, $98 \%$ of SMEs dominated to more than $65 \%$ of employments opportunities and contributed to more than $50 \%$ of the country's gross domestic product (GDP). For example, SMEs contributions in GDP/total value were $50 \%$ in Korea, $55.3 \%$ in Japan and $60 \%$ in China. In Malaysia, SMEs contribution was valued at $47.3 \%$ (Normah, 2006). In addition, SMEs had also been widely recognized as the backbone of Malaysian economic due to their strong contributions in promoting endogenous growth in industry expansion and development (Saleh and Ndubisi, 2006). This has further warrant for more attention to be given to SMEs in assisting their development.

Globalization and open market phenomena have augmented many businesses' operations. They create a new way of doing businesses. Efficient and effective business processes and activities are strongly demanded. Local businesses are not only competing with each other but with multinational companies, which are supported with abundant resources to produce high quality products with reasonable pricing. This increases the pressure on local businesses, in particular to the management to increase business efficiency by making better judgement on business decisions. Real time data and reports would certainly be a considerable assistance to help managers make more informed decisions (Ismail, Abdullah, \& Tayib, 2003).

The requirements for updated data in supporting decision making have been increasingly essential particularly for SMEs (El Louadi, 1998). This is because, SMEs face competitive pressure not only from within the SMEs industries and other larger firms, but they also have to compete with giant multinational companies. Informed decisions will enable SMEs to increase business efficiency and remain competitive. Thus, the adoption of accounting information system is expected to provide SMEs with the right capabilities and resources in achieving these objectives.

In corresponding with the increasing dependency for high quality information for decision making, managements need assurance that they are obtaining relevant and reliable information at the right time with a reasonable cost. Assurance could be achieved via advice from professionals to improve decision making quality (Marriot and Marriot, 2000) or from internal control systems utilize by the companies (Kinney, 2000). Nevertheless, study indicated that these information systems, specifically the accounting information systems are underutilized (Gupta and Capen (1996), especially in SME companies (Marriot and Marriot, 2000).

In Malaysia, various studies on information system success and information system impact on firms' performance have been conducted by Foong (1999), Hussein and Karim (2007) and Ismail (2007). In addition, Ismail and King (2007) had conducted a study on the impact of information system alignment with company's objectives in manufacturing companies. They have found out that firms in the aligned group usage of informational sophistication differ considerably from the non-aligned group firms. The difference is highly significant in analytical based applications. In other words, it was noted that applications such as financial analyst, project management, budget variances, modelling, and personnel management have been poorly utilized by SMEs. This finding supported the observation that Malaysian companies, in particular the SME are still far behind from achieving the optimal utilization of information system.

Research in information systems is well aware that information system does not directly affect organizational performance (Le Blanc \& Kozar, 1990). The system must be used and exploited to achieve its intended objectives. Therefore, before moving towards adopting more sophisticated and advanced information systems; such as Enterprise Resource Planning system (ERP), Customer and Relationship Management system (CRM) and Human Resource Management system (HRM), it is important to determine SMEs current usage of existing information systems. SMEs current usage levels would be a good indicator to assess the benefits of employing a new advance system. This is because low usage of existing information system would imply that these companies are still not ready to adopt a more advance system. This situation will raises further questions on why these firms need more information when they do not even fully utilize their current information. In 2003, Ismail et al. (2003) highlighted that accounting systems adoption in Malaysian SMEs were still at the infancy stage and majority of these firms were only maintaining basic accounting systems. Nevertheless, this study had been conducted six years before and many have changed since then. Malaysian citizens' computer literacy and usage 
have increases and the country's educational performances have shown significant improvement. Therefore, it is paramount to investigate whether Malaysian SMEs have matured, particularly in information system utilization. More specifically to the impact of accounting information system usage on firms' performance. Hence, the objective of this study is to provide empirical evidence on Malaysian SMEs performance after the implementation of accounting information system.

Accordingly, in section 2 is the literature review where we will discuss the common view on accounting information system and further differentiate the definition between financial accounting and management accounting. This will provide better understanding on the accounting data prepared for the purpose of complying with external requirements and data prepared to improve organizational performance. We will also discuss on previous research findings regarding SMEs usage of accounting information system and the system impact on organization's performance. Section 3 represents data collection method. A brief descriptive statistic on data that have been analyzed is also included at the end of this section. In section 4, we will provide explanation on how the panel data was analysed. Finally, in section 5 and 6, we will discuss and summarise the analysis from the results obtained.

\section{Literature Review}

\subsection{Information System In SMEs}

It is common knowledge that the main objective of a business is to maximise profit either in terms of increases in business productivity or by achieving rapid expansion in market shares domination. To achieve this goal, businesses need to be responsive to the changes in the environments, in particular to the information technology revolution. Nowadays, information technology is a must in many businesses. It is difficult to gain competitive advantage and survive without some adoption or implementation of this advancement in technological products. Studies has shown that the most widely use information system is accounting information system, specifically in financial reporting aspects (Marriot and Marriot, 2000; Riemenschneider and Mykytyn Jr, 2000; and Ismail, 2007).

Romney and Steinbart (2000) define an accounting information system as 'a system that processes data and transactions to provide users with information they need to plan, control and operate their businesses. Here, accounting information systems are viewed as a system that helps management in planning and controlling processes by providing relevant and reliable information for decision making. It suggests that accounting information system functions are not solely for the purpose of producing financial reports. It role goes beyond this traditional perspective. Accounting information system should be utilized to include planning and managing business activities. It could also be used as a controlling mechanism such as budgeting. Therefore, full adoption of the system is essential to fully attain the system's benefits.

In general, financial accounting data has been commonly defined as information prepared for external users such as creditors, investors and suppliers. Nevertheless, its functions could also be extended to include providing managers with useful data for making informed decisions or commonly known as management accounting. Both information, financial and management accounting information come from the same sources of data; the only difference is in the way these data are presented. In management accounting, information is gathered, collate and presented in a way uniquely requested by management. This will allow managers to immediately locate the information that is useful for them. Alternatively, in financial accounting, reports are prepared in accordance to the regulators' guidelines.

Traditionally, accounting information systems have been perceived as a means of providing financial information to organization (Mia, 1993). There has been considerable evidence that within SME financial accounting has remained the principle source of information for managers (Holmes and Nichols, 1988, McMahon and Davies, 1994, Nayak and Greenfield, 1994, Mairead, 1977). These studies have also found out that SMEs are still having ineffective information management, poor system control, and most decision making is on ad hoc basis despite having adopted accounting information system. Mauldin and Ruchala (1999) reason that this situation could be attributed to the initial objectives of information technology (IT) adoption. The accounting system original role of replacing manual accounting process (Mauldin \& Ruchala, 1999) has hindered further usage and exploration on the system benefits. Marriot and Marriot (2000) further concluded that financial awareness among SMEs' managers varies considerably and the use of computers for the preparation of management accounting information is not at its full potential.

However, Perrent and Grant (2000) suggested that SMEs do implement effective information and control through informal means and that decision making process can be more sophisticated than anticipated. They argued that these contradiction stems largely from the researchers' paradigm rather than any real contradiction. 
In addition, Ismail and King (2005) found that some SME managers are capable of using IT strategically rather than focusing on administrative efficiency suggesting that the use of IT has expand towards management accounting context.

\subsection{Information System Impact on Firms' Performance}

SMEs accounting information system implementation and success have been extensively researched. Recent research development focuses on the relationship between firms strategies alignment with information system (Tan, 1996; Li and Ye, 1999). These studies suggested that there are positive relationship between strategy and strategic information technology. A study conducted by Shin (2001) discovered that IT investments will be more efficient if the systems implementation is allign with the firms' strategy. This argument is supported by Cragg et al. (2002) asserting that IT implementation which is allign with business strategy prove to have positive impact on firms' performance. In addition, Davenport (1998) highlighted the importance of having a good fit between firms' requirement and technology capabilities. The mismatch between what is needed by the firms and service offered by the new technology will yield poor performance. Nevertheless, HyvÖnen (2007) also added that sophisticated information technology aligned with ineffective performance measure will yield lower performance outcome. This raises the need for careful planning and strong justification process to be undertaken before firm reaches the decision to implement an information system. This issue is more profound within SMEs due to their limited resources and experience in IT field (Mitchell, Reid, \& Smith, 2000).

Other authors (Bruque, 2007; Riemenschneider et.al, 2003) investigated factors that influence the adoption of information technology in SMEs. Both authors generally agreed that SMEs adoption of information technology were mainly influenced by the perceived benefits of implementing the systems and stems from the pressures received from competitors, customers, and suppliers to ensure business continuity and survival in the increasingly competitive environment.

Many firms invest in advanced information technology aiming at collecting more information to assist decision making performance which will eventually lead to improve efficiency and firms' profitability. Study showed that firms' that acquire extensive IT resources are able to create competitive advantage (King, 1989). Nevertheless, prior researches have difficulty providing evidence on positive relationship between IT investments and firms' performance (Mahmood \& Mann, 1993; Ismail, 2007). Mixed and inclosclusive findings suggesting that a more in depth analysis is required.

\section{Data}

Data for this study was collected from SMEs in Klang Valley. Klang Valley was chosen since it is known as the hub of Malaysia SMEs businesses as almost 48.8\% (http://www.smeinfo.com.my) of Malaysian SMEs are located in this area. In addition, the study conducted by Saleh and Ndubisi (2006), have mentioned that majority of SMEs are located in the central part of this country. Financial statement data were gathered for a five years period commencing from year 2004 to 2008. Questionnaires were sent to various SMEs industries. Financial firms such as investment firms are excluded from this sample due to the different nature of their business. Firms that have missing value for selected variables which were used in this study were also excluded from this sample. Thus, the final sample of this study comprises of 205 firm-years. In addition, limited number of response received inhibited further classification of these SMEs according to their respective industries.

Dependent variable used in this study was firm performance. Return on assets (ROA) was used as a proxy for firm performance. We measure ROA as net income over total assets. Dummy variables were used to indicate firm that had adopted accounting system (AS) and firm that did not adopt any accounting system, whereby, 1 represent firm using Accounting Information System such as UBS and MYOB; and 0 represent firm that does not adopt any Accounting Information System. Firm size and leverage were used as control variables. Natural logarithm of total assets (LNTA) was used as a proxy for firm size and debt ratio (DR) was used as a proxy for firm leverage. The measurement of debt ratio is obtained from the total debt scaled by firm's total assets equation. This study hypothesize that there is a positive relationship between the use of accounting information system and firm's performance.

Table 1 presents the descriptive statistics for the sample of this study. The average cash conversion cycle is 1.626 indicating that firm obtained RM1.626 for every RM1 invested in total asset. The average of natural log of firms' total asset is 14.698 with standard deviation is at 1.176 . In addition, the result of the descriptive analysis also highlighted that in average, it is noted that $53.3 \%$ of firms' asset was financed by total debt.

\section{Methodology}

In achieving this study objective, panel data is more relevant because it contains the necessary mechanism to deal with both inter-temporal dynamic behaviour and the individualistic of the firms. For example, it allows 
controlling for heterogeneity bias due to the confounding effect of time-invariant variables omitted or hidden factors from the regression model. Besides, this longitudinal approach provides additional information and richer source of variation through utilisation of a large number of data points, in which increasing the degrees of freedom and reducing the collinearity among explanatory variables, thus improving the efficiency of econometric estimators (Hsiao, 1986). All of these benefits provide stronger conclusion than findings derived from the use of static cross-sectional data or time series setting alone. This panel data estimation is more robust compared to solely time series estimation. This is because we could obtain larger sample size once we have pooled together all data across firms and time period.

\subsection{Pooled OLS Estimation}

This study hypothesize that the explanatory variables have a linear relationship with the firm performance. Since panel data is utilize, it does not only enables the researchers to consider both time series and cross sectional characteristic of the samples, but it also helps to identify the sources of possible mixed effects and the importance of each explanatory variables in influencing firm performance. At this initial stage, the regression model is assumed to have a constant intercept and slope coefficients. The relationship is expresses as follows:

$$
\begin{gathered}
Y_{i t}=\alpha+X_{i t} \beta+\varepsilon_{i t} \\
\text { for } \quad \mathrm{i}=1,2, \ldots \ldots \mathrm{N} . \\
\mathrm{t}=1,2, \ldots \ldots \mathrm{T} .
\end{gathered}
$$

where;

$Y_{i t}$ is the dependent variable (ROA) pooling $\mathrm{N}$ cross sectional observations

and T time series observations;

$\alpha$ is the intercept or constant;

vector $X_{i t}$ contains $\mathrm{K}$ explanatory variable for firm i in year $\mathrm{t}$;

vector $\beta$ contains $\mathrm{K}$ regression coefficients or parameters to be estimated;

$\varepsilon_{i t}$ is the error term or disturbance term and by assumptions $\mathrm{E}\left(\varepsilon_{i t}\right)=0$ and $\operatorname{Var}\left(\varepsilon_{i t}\right)=\sigma_{\varepsilon}^{2}$.

With the assumption that the disturbance terms $\varepsilon_{i t}$ are independent and identically distributed and have zero means, $\mathrm{E}\left(\varepsilon_{i t}\right)=0$ and constant variances $\operatorname{Var}\left(\varepsilon_{i t}\right)=\sigma_{\varepsilon}^{2}$ and all the other classical assumptions hold. Equation (1) above can be directly estimated by usual pooled OLS approach. Under such conditions, the pooled OLS would yield an unbiased, consistent and efficient or Best Linear Unbiased Estimator (BLUE) estimator of $\beta$. It should be noted that this study used the balance panel data. But for simplicity purposes, it is assumed that $\mathrm{T}$ is the same for all firms to keep the formula notation clear and simple. This equation can be expressed as follows:

$\mathrm{ROA}_{i t}=\beta_{0}+\beta_{1} \mathrm{AS}_{i t}+\beta_{2} \mathrm{LNTA}_{i t}+\beta_{3} \mathrm{DR}_{i t}+\varepsilon_{i t}$

where

$\mathrm{ROA}_{i t}=$ Return on assets of firms, $\mathrm{AS}_{i t}=$ firm that use accounting system, $\ln T A_{i t}=$ natural log of total asset as a proxy for firm size, $\mathrm{DR}_{i t}=$ debt ratio as a proxy for financial leverage, $\varepsilon_{i t}$ the disturbance, and $\beta_{0}$ is intercept. The indices $i$ and $t$ denote firm and time respectively.

\section{Analysis of Results}

Table 2 presents the pooled OLS estimates of return on assets with explanatory variables and analysis of their relationships. In addition, random effect estimated was also carried out and compared with the pooled OLS specification. At this point, we assumed a static model in level and test whether the structure of error term is adequately captured. Since, pooled data typically exhibit serial correlation, cross-sectional correlation and groupwise heteroskedasticity (Greene, 2000: 592-608), we expect to find such structural residuals.

Furthermore, Table 2 reports the coefficient and the level of significant of the explanatory variables particularly for firms that use accounting information system (AS) and also the impact of control variables which comprises of firm size (LNTA) and debt ratio (DR). Based on the random effects model, the results revealed that explanatory variables are significantly associates with firm performance with the expected sign. AS is positively related to firm performance at significant level of 5\%. This provides empirical evidence that firms adopting or using accounting information system had significantly increased their firms' profitability and performance. This is consistent with Rashid, Hossain \&Patrick (2001) observation that the implementation of accounting information system does improve business operation and this lead to increases in firm's performance. When 
SMEs do use AS, they would be able to collect more information to assist decision making. This revealed that SMEs have the ability to create competitive advantage due to improvement in efficiency and firms' profitability.

Control variables show that firm size has a negative relationship with firm performance at significant level of $1 \%$. This finding contradicts to previous studies' findings which indicated that firm size is supposed to increase firm performance. However, referring to García-Morales, Lloréns-Montes and Verdú-Jover (2007) study, contradictive findings of this study is largely due to large-firm management fundamental which is diverse from SMEs. This is consistent with Moen (1999) suggestion that small firms have different competitive advantages from larger firms. Therefore, conclusions drawn from previous studies on big firms or organizations listed in exchange would not be appropriate to be applied in SMEs context without empirical confirmation. Meanwhile, leverage is found to be negatively related to firm performance at $1 \%$ significance level. This explains that firms with high debt do not fully utilize (capital that acquired from debt financing) their capital towards investments opportunities thus affecting firms' performance. This commonly occurs when the profit gain is less than the cost they need to bear from debt financing such as interest expenses. This situation could be attributed to lack of expertise to effectively manage their financial resources or due to firms' limited capabilities in making a more informed investments decision. Hence, these limited resources and capabilities would eventually hurt firm's performance in achieving better profitability.

For both models and data sets, the LM test rejects the null hypothesis as the intercepts and slopes are the same across firms. Therefore, we could not use the pooled OLS estimator (Table 2) for impact of accounting system model. Hence, this implies that random effects model is more suitable than OLS model (pooled model). This is the reason why in the results discussion above, we prefer to explain the results from random effects model view. In addition, the random effects specification provides evidence that the random effects specification is preferable. In other words, the intercepts vary and the slopes are the same across firms, which indicate that every firm has their own financial decision policies.

\section{Conclusion}

Information system had been widely used by many corporations to automate and integrate their business operations. The main objectives of many businesses to adopt this system are to improve their organizational efficiency and increase competitiveness ability. Prior researches have shown that information system adoption does increases firm's performance and operations efficiency. In Malaysia, SMEs have been targeted as a mechanism in generating domestic-led investment to stimulate economic development, particularly after the economic crisis in 1997. Thus, it is crucial for SMEs to adopt information systems specifically AS for their business operation. This is because SMEs face competitive pressure not only from within the SMEs industries but also from the larger firms. Informed decisions would enable SMEs to improve business efficiency and remain competitive. Thus, the adoption of accounting information system could provide SMEs with the right capabilities and resources in achieving these objectives. In encouraging SMEs adoption of the information systems, Malaysian government have allocated special grants to assist SMEs to acquire these systems. Results from this study revealed that SMEs that use accounting information system do increase their firm performance. Hence, we would suggest that SMEs take the opportunity on the grants provided by government to acquire AS such as MYOB, UBS and a more advance system like ERP to make them more competitive.

\section{References}

Cragg, P. B., King, M. R., \& Hussin, H. (2002). IT allignment and firm performance in small manufacturing firms. Journal of strategic information systems, 109-132.

Davenport, T. H. (1998). Putting the Enterprise into the Enterprise System, July/August. 121-130. Harvard Business Review.

El Louadi, M. (1998). The relationship among organization structure, information technology and information processing in small Canadian firms. Canadian Journal of Administrative Sciences , 15 (2), 180-199.

Elliot, R. K. (1992). The third wave breaks on the shores of accounting. Accounting Horizons, 6 (2), 61-85.

Fisher, B., \& Kenny, R. (2000). Introducing a business information system into an engineering company. Journal of Information, Knowledge and Systems Management , 2, 207-221.

Foong, S.Y. (1999), Effect of end user personal and systems attributes on computer-based information system success in Malaysian SMEs, Journal of Small Business Management, July, pp 81-87. 
García-Morales, V.J., Lloréns-Montesand, F.J., Verdú-Jover, A.J. (2007). Influence of personal mastery on organizational performance through organizational learning and innovation in large firms and SMEs. Technovation, 27(9), 547-568.

Gupta, U.G. and Capen, M. (1996). Techniques, An empirical investigation of the contribution of IS to manufacturing productivity, Information and Management, 31, pp 227-233.

HyvÖnen, J. (2007). Strategy, Performance measurement techniques and information technology of the firm and their links to organizational performance, Management Accounting Research, 18, pp 343-366.

Ismail, N. A. (2007). The impact of information technology on performance: The mediating role of management accounting systems. Jurnal Teknologi, 46 (E), 27-44.

Ismail, N. A., Abdullah, A. N., \& Tayib, M. (2003). Computer-based accounting systems: the case of manufacturing-based small and medium enterprises in the Northern Region of Peninsular Malaysia. Jurnal Teknologi, 39 (E), 19-36.

King, W. R. (1989). Using information and Information Technology for Sustainable Competitive Advantage: Some Empirical Evidence. Information and Management, 17, 87-93.

Kinney, W.R. (2000). Information Quality Assurance and Internal Control for Management Decision Making, Boston: Irwin/McGraw Hill.

Li, M. and Ye, L. (1999). Information technology and firm performance: Linking with environmental, strategic and managerial context, Information Management, 35, pp 43-52.

Mahmood, M. A., \& Mann, G. J. (1993). Impact of information technology investment: An empirical assessment. Accounting, Management \& Infomation Technology , 3 (1), 23-32.

Marriot, N and Marriot, P (2000). Professional accountants and the development of a management accounting service for the small firm: barriers and possibilities, Management accounting research, 11, pp 475-492.

Mia L. (1993). The Role of MAS information in organisations: An empirical study. Br Account Rev; 25: 269-285.

Mitchell, R., Reid, G. \& Smith, J. (2000). Information system developement in the small firm. United Kingdom: CIMA Publishing.

Moen, O. (1999). The Relationship Between Firm Size, Competitive Advantages and Export Performance Revisited. International Small Business Journal, 18(1), 53-72.

Porter, M. E. (1980). Competitive Strategy: Techniques for analyzing industries and competitors. New York: The Free Press.

Rashid, M., Hossain, L., and Patrick, J. (2001). The Evolution of ERP Systems: A Historical Perspective. In L. Hossain, J. Patrick, \& M. Rashid, Enterprise Resource Planning: Global Opportunities \& Challenges (pp. 1-16). United States of America: Idea Group Publishing.

Riemenschneider, C. K. and Mykytyn Jr, P. P. (2000). What small business executives have learned about managing information technology, Information and Management, 37, pp 257-269.

Romney, M. B. and Steinbart, P. J. (2000). Accounting Information Systems (8 ${ }^{\text {th }}$ Edition), Reading, MA: Addison-Wesley.

Sharman, P. A. (2003). The case for Management Accounting, Strategic Finance.

Shin, N. (2001). The impact of Information Technology on Financial Performance: The importance of Strategic Choice. European Journal of Information Systems , 227-236.

Tan, R.R. (1996). Information technology and perceived competitive advantage: an empirical study of engineering consulting firms in Taiwan, Construction Management Economics. 14, pp 227-240.

Vaasen, E.H.J. (2002). Accounting Information Systems, A Managerial Approach, John Wiley \& Sons Ltd.

Table 1. Descriptive Statistic

\begin{tabular}{|l|l|l|l|l|}
\hline & ROA & AS & LNTA & DR \\
\hline Mean & 1.626 & 0.439 & 14.698 & 0.533 \\
\hline Std dev. & 1.565 & 0.497 & 1.176 & 0.335 \\
\hline
\end{tabular}


Table 2. Regression Analysis of Impact of Accounting System

\begin{tabular}{|c|c|c|}
\hline Explanatory variable & Pooled OLS & Random Effects \\
\hline AS & $0.794^{* * *}$ & $1.024^{* *}$ \\
& $(0.001)$ & $(0.017)$ \\
\hline LNTA & $-0.528^{* * *}$ & $-0.892^{* * *}$ \\
& $(0.000)$ & $(0.00)$ \\
\hline DR & $-0.438^{* * *}$ & $-0.743^{* * *}$ \\
& $(0.000)$ & $(0.000)$ \\
\hline Constant & $9.009^{* * *}$ & $14.397^{* * *}$ \\
& $(0.000)$ & $(0.000)$ \\
\hline LM test & \multicolumn{2}{|c|}{0.0000} \\
\hline
\end{tabular}

Notes: ${ }^{* * *}$ Significant at $1 \%,{ }^{*}$ Significant at $5 \%$, Parentheses are $p$-values. 